\title{
Pengembangan Modul Praktikum Fisika Berbasis Open Ended Problem Pada Pokok Bahasan Getaran Harmonis
}

\author{
${ }^{1}$ Dinni Wachidatun Niklah, ${ }^{2}$ Puji Hariati Winingsih, ${ }^{3}$ Ayu Fitri Amalia \\ ${ }_{1,2,3}$ Program Studi Pendidikan Fisika, FKIP, Universitas Sarjanawiyata Tamansiswa, Jl. Batikan \\ UH. III/1043 Telp. 0274-375637, Faks. 0274-547042. \\ Email Korespondensi:dinniwachidah998@gmail.com
}

\begin{tabular}{|c|c|}
\hline & Ibstract \\
\hline & \multirow{2}{*}{$\begin{array}{l}\text { Development Of Physics Practicum Modules Based On Open Ended Problem } \\
\text { On The Subject Of Harmonic Vibration. This study aims to develop and test } \\
\text { the feasibility of physics practicum modules based on open ended problems on } \\
\text { the subject of harmonic vibrations. This research type is research and } \\
\text { development ( } R \text { \& D) by Sugiyono using } 8 \text { stages, namely potential and } \\
\text { problems, data collection, product design, validation of practicum modules, } \\
\text { improvement of practicum modules, practicum module trials, revision of } \\
\text { practicum modules, and final products. The feasibility test for practicum } \\
\text { module based on open ended problem uses a Likert scale questionnaire with } \\
\text { validation by two validators. Research subjects MIPA MAN } 5 \text { Cirebon } \\
\text { students, amounting to } 9 \text { students. The instrument used in the form of practical } \\
\text { modules and questionnaire responses of students. The results of this research } \\
\text { and development analysis were produced by practicum module products based } \\
\text { on open ended problems on the subject of harmonic vibrations with an average } \\
\text { validator score of } 5.00 \text { or (100\%) with the Very Good (SB) category and the } \\
\text { average score of students } 4,02 \text { (80.40\%) included in the Good category (B). So } \\
\text { it can be concluded that the development of physics modules based on open } \\
\text { ended problems is feasible to be used as practical teaching materials. }\end{array}$} \\
\hline & \\
\hline Infor & \\
\hline & \multirow{2}{*}{$\begin{array}{l}\text { Penelitian ini bertujuan untuk mengembangkan dan menguji kelayakan modul } \\
\text { praktikum fisika berbasis open ended problem pada pokok bahasan getaran } \\
\text { harmonis. Jenis penelitian ini adalah penelitian dan pengembangan (R \& D) } \\
\text { oleh Sugiyono menggunakan } 8 \text { tahap, yaitu potensi dan masalah, pengumpulan } \\
\text { data, desain produk, validasi modul praktikum, perbaikan modul praktikum, } \\
\text { ujicoba modul praktikum, revisi modul praktikum, dan produk akhir. Tes } \\
\text { kelayakan modul praktikum berbasis open ended problem menggunakan } \\
\text { kuesioner skala likert dengan divalidasi oleh dua validator. Subjek penelitian } \\
\text { peserta didik MIPA MAN } 5 \text { Cirebon yang berjumlah } 9 \text { peserta didik. Instrumen } \\
\text { yang digunakan berupa modul praktikum dan angket tanggapan peserta didik. } \\
\text { Hasil analisis penelitian dan pengembangan ini dihasilkan oleh produk modul } \\
\text { praktikum berbasis open ended problem pada pokok bahasan getaran harmonis } \\
\text { dengan skor rata-rata validator } 5,00 \text { atau ( } 100 \%) \text { dengan kategori Sangat Baik } \\
\text { (SB) dan skor rata-rata peserta didik } 4,02(80,40 \%) \text { termasuk dalam kategori } \\
\text { Baik (B). Jadi dapat disimpulkan bahwa pengembangan modul praktikum } \\
\text { fisika berbasis open ended problem layak untuk digunakan sebagai bahan ajar } \\
\text { praktikum. }\end{array}$} \\
\hline & \\
\hline
\end{tabular}

Sitasi: Niklah, DW., Winingsih, PH., Amalia, AF. (2020) Pengembangan Modul Praktikum Fisika Berbasis Open Ended Problem Pada Pokok Bahasan Getaran Harmonis. Kappa Journal. 4 (2), 256-262 


\section{PENDAHULUAN}

Pendidikan merupakan suatu hubungan antara manusia dengan lingkungannya yang melakukannya secara sadar dan juga terencana guna mengembangkan segala potensi, baik jasmani maupun ruhani, dengan tujuan untuk menimbulkan perubahan positif dan kemajuan, baik kognitif, afektif, maupun psikomotorik (Rulam A, 2014:38).

Pendidikan Indonesia saat ini menggunakan kurikulum 2013 yang menggunakan konsep "Student Centered". Pembelajaran dalam kurikulum 2013 mengubah pola pembelajaran pasif menjadi pembelajaran kritis. Praktikum merupakan bagian dari suatu pengajaran kepada peserta didik yang bertujuan agar peserta didik mendapat pengalaman yang nyata untuk menguji dan melaksanakan suatu teori yang sudah didapat (Suharso, 2011:38).

Berdasarkan hasil observasi dan wawancara terhadap guru fisika MAN 5 Cirebon, peserta didik kurang memahami suatu konsep jika belum melakukan praktikum, oleh karena itu perlu adanya suatu pembaharua dalam proses pembelajaran yag bukan hanya menyampaikan materi saja, akan tetapi juga melakukan percobaan secara langsung dengan adanya suatu praktikum. Salah satu strategi belajar yang dapat memberikan pengalaman empirik kepada peserta didik dalam belajar fisika adalah dengan metode praktikum (Anisa A.P dkk, 2020:28).

Di MAN 5 Cirebon juga tidak semua materi yang telah disampaikan oleh guru dipraktikumkan, dikarenakan alat praktikum di sekolah kurang lengkap dan juga tidak adanya modul praktikum. Pembuatan modul praktikum juga hendaknya diperhatkan pendekatan pembelajaran yang dapat memaksimalkan pemahaman peserta didik akan konsep-konsep fisika.

Salah satu pendekatan yang dapat memaksimalkan pemahaman konsep, menganalisa masalah yang terbuka, serta meningkatkan pengalaman langsung peserta didik adalah pendekatan open ended problem. Open ended problem merupakan suatu pendekatan dalam pembelajaran yang menyajikan suatu permasalahan terbuka yang memiliki penyelesaian lebih dari satu jawaban yang benar. Menurut Becker dan Epstein (dalam Wijaya, 2012:74).

Pendekatan open ended problem sebelumnya sudah dilakukan penelitian oleh Ayel Sarwono Lahra dkk (2017), yang berjudul "Pengembangan modul praktikum berbasis pendekatan Open Ended Problem untuk meningkatkan kreativitas siswa", menunjukkan bahwa terdapat peningkatan kreativitas peserta didik dan memperoleh respon peserta didik sebesar 78,13\% dengan kategori baik. Penelitan ini menggunakan pengembangan ADDIE dengan sampel kelas XI IPA yang berjumlah 25 peserta didik (Ayel Sarwono Lahra dkk, 2017).

Berdasarkan latar belakang masalah, maka dapat didefinisikan masalahnya yaitu: banyak peserta didik MAN 5 Cirebon yang mengeluh tentang sulitnya pelajaran fisika apabila tidak dipraktikumkan, pembelajaran di sekolah belum melakukan praktikum secara maksimal, dikarenakan alat praktikum kurang memadai, dan tidak adanya bahan ajar seperti modul praktikum dan modul praktikum yang digunakan di MAN 5 Cirebon kebanyakan tidak menggunakan pendekatan pembelajaran.

Batasan masalah yang diteliti akan dibatasi pada fokus penelitian ini adalah pengembangan media pembelajaran berupa modul praktikum fisika pada pokok bahasan getaran harmonis, modul praktikum fisika yang dikembangkan menggunakan pendekatan open ended problem, open ended problem yang digunakan terbatas pada proses pemecahan masalah yang terbuka untuk menemukan penyelesaian lebih dari satu jawaban yang benar dan modul praktikum yang dikembangkan adalah modul praktikum pada pokok bahasan getaran harmonis. 


\section{METODE}

Penelitian ini akan dilaksanakan di MAN 5 Cirebon tahun ajaran 2020/2021. Penelitian ini merupakan jenis penelitian pengembangan (Research and Development). Untuk itu penelitian ini bertujuan untuk menghasilkan sebuah modul praktikum fisika berbasis open ended problem pada pokok bahasan getaran harmonis. Menurut $\mathrm{R}$ Borg dan Meredith Darmein Gall (2007:589) "penelitian dan pengembangan adalah pengembangan yang berbasis industri di mana temuan dan hasil penelitiannya digunakan untuk merancang produk pembelajaran yang kemudian dilakukan uji lapangan secara sistematis, dievaluasi dan disempurnakan sampai memenuhi standarisasi tertentu dengan diketahui efektivitas, kualitas, atau standar yang sama dari kriteria yang digunakan".

Prosedur pengembangan yang akan digunakan dalam penelitian ini adalah prosedur pengembangan model Borg \& Gall yang telah dikembangkan oleh Sugiyono, adapun langkah-langkah penelitian dan pengembangan adalah potensi dan masalah, pengumpulan data, desain produk, validasi desain, revisi desain, ujicoba produk, revisi produk, ujicoba produk, ujicoba pemakaian, revisi produk, dan produksi masal. Karena terdapat keterbatasan waktu dan biaya maka dalam penelitian ini hanya dilakukan tahap persiapan dan pengembangan bahan ajar, serta ujicoba terbatas mengingat metode penelitian yang dikembangkan Sugiyono ini membutuhkan biaya dan waktu pelaksanaan yang relatif lama (Sugiyono, 2013:409).

Objek dalam penelitian ini adalah modul praktikum fisika berbasis open ended problem pada pokok bahasan getaran harmonis. subjek dalam penelitian inni yaitu dua orang validator dan 9 orang peserta didik sebagai responden.

Teknik pengumpulan data dilakukan dengan cara observasi dan wawancara secara offline dan online di MAN 5 Cirebon untuk memperoleh informasi tentang bahan ajar praktikum, serta memberikan instrumen penilaian kepada validator dan kuesioner kepada peserta didik pada responden sebagai masukan dan saran untuk menyempurnakan modul praktikum berbasis open ended problem sebelum menjadi produk akhir.

Teknik analisis yang digunakan untuk menganalisis data hasil validasi dari validator dan respon peserta didik sebagai berikut:

a. Mengubah nilai menjadi kualitatif menjadi kuantitatif seperti yang ditunjukkan pada Tabel 1 berikut ini.

Tabel 1. Konversi Nilai Kualitatif menjadi Kuantitatif

\begin{tabular}{ll}
\hline Keterangan & Skor \\
\hline Sangat Setuju (SS) & 5 \\
Setuju (S) & 4 \\
Kurang Setuju (KS) & 3 \\
Tidak Setuju (TS) & 2 \\
Sangat Tidak Setuju (STS) & 1 \\
\hline
\end{tabular}

b. Menghitung rata-rata nilai tiap komponen dengan menggunakan persamaan:

$$
x=\frac{\sum x}{n}
$$

Keterangan:

$x=$ Skor rata-rata,

$\sum x=$ Jumlah skor,

$n=$ Jumlah penilai.

c. Menghitung jarak interval dengan menggunakan persamaan (Eko Putro Widoyoko, 2017:110) 


$$
\begin{aligned}
& (i)=\frac{\text { skor tertinggi-skor terendah }}{\text { jumlah kelas interval }} \\
& \text { (i) }=\frac{5-1}{5} \\
& (i)=0,8
\end{aligned}
$$

d. Mengubah rata-rata skor menjadi bentuk kualitatif. Tabel 2 di bawah ini merupakan konversi nilai rata-rata menjadi bentuk kualitatif adalah sebagai berikut (Eko Putro Widoyoko, 2016:242)

Tabel 2. Konversi Nilai Kuantitatif Kualitatif Skor Validator

\begin{tabular}{ll}
\hline Skor Rata-Rata & Klasifikasi Kategori \\
\hline $4,2 \leq \overline{\mathrm{x}} \leq 5,0$ & Sangat baik \\
$3,4 \leq \overline{\mathrm{x}}<4,2$ & Baik \\
$2,6 \leq \mathrm{x}<3,4$ & Cukup baik \\
$1,8 \leq \overline{\mathrm{x}}<2,6$ & Kurang baik \\
$1,0 \leq \overline{\mathrm{x}}<1,8$ & Tidak baik \\
\hline
\end{tabular}

Pengolahan Respon Angket Peserta Didik yaitu sebagai berikut:

a. Pemberian Skor

Jawaban pada setiap item diberi skor dengan menggunakan Skala Likert. Skala penilaian skala likert menurut Eko Putro Widoyoko (2017:105) sesuai dengan tabel berikut :

Tabel 3. Penilaian Skala Likert

\begin{tabular}{ll}
\hline Jawaban Item Lembar Penilaian & Skor \\
\hline Sangat setuju & 5 \\
Setuju & 4 \\
Kurang setuju & 3 \\
Tidak setuju & 2 \\
Sangat tidak setuju & 1 \\
\hline
\end{tabular}

b. Pengolahan Skor

Pengolahan skor angket peserta didik berjumlah 9 orang dengan pengolahan datanya sesuai dengan tahapan yang dikemukakan oleh Eko Putro Widoyoko (2017:110-111) sebagai berikut :

1. Menjumlahkan skor responden pada setiap komponen yang dianalisis. Pada penelitian ini jumlah responden yang digunakan adalah 9 peserta didik.

2. Menghitung skor rata-rata setiap komponen penilaian pada persamaan 1 .

3. Menghitung jarak interval pada persamaan 2 .

\section{HASIL DAN PEMBAHASAN}

Penelitian ini merupakan penelitian pengembangan menurut Sugiyono yang dilaksanakan di MAN 5 Cirebon. Hasil penelitian ini berupa modul praktikum fisika berbasis Open Ended Problem pada pokok bahasan getaran harmonis.

Tahapan yang dilalui dalam pengembangan modul praktikum ini adalah potensi masalah, pengumpulan data, desain produk modul praktikum, validasi produk modul praktikum, revisi modul praktikum serta produk akhir. Pada penelitian ini tidak dilaksanakan tahapan selanjutnya seperti yang dipaparkan oleh Sugiyono yaitu uji coba pemakaian, revisi produk, serta produksi massal, dikarenakan keterbatasan waktu dan biaya.

Dengan demikian, penentuan kelayakan produk yang berupa modul praktikum ini ditentukan oleh hasil validasi dari ahli materi dan data hasil angket peserta didik. Potensi dan masalah diperoleh dari hasil observasi sekolah yang bertempat di MAN 5 Cirebon. 
Observasi ini dilaksanakan dengan mengamati fasilitas laboratorium serta alat-alat praktikum yang ada di MAN 5 Cirebon dan melakukan wawancara dengan guru fisika di MAN 5 Cirebon. Hasil observasi berupa pengamatan dan wawancara di MAN 5 Cirebon di mana pembelajaran fisika pada pokok bahasan getaran harmonis belum terdapat modul praktikum yang menggunakan pendekatan Open Ended Problem yang dikembangkan sendiri oleh guru. Berdasarkan wawancara diperoleh informasi bahwa masih banyak peserta didik yang mengalami kesulitan dalam memahami materi getaran harmonis, hal ini dikarenakan sekolah jarang melakukan praktikum karena masih adanya keterbatasan alat dan bahan praktikum. Berdasarkan masalah di atas, maka diperlukan adanya pengembangan modul praktikum fisika berbasis Open Ended Problem pada pokok bahasan getaran harmonis.

Selain itu, berdasarkan penelitian terdahulu dari Siti Nurul Fitriyani (2017) yang berjudul "Pengembangan Modul Fisika Berbasis SETS untuk Memberdayakan Kemampuan Berpikir Kritis Siswa", penelitian tersebut dilakukan pada dua ujicoba, skala luas dan skala kecil. Ujicoba berskala kecil dilakukan di kelas XI MA dengan menggunakan 10 siswa. Hasil penilaian dari 10 siswa tersebut menunjukkan nilai maksimal dengan persentase $100 \%$ ideal, sedangkan ujicoba berskala besar dilakukan di kelas XI MA Darul Muhsin sebanyak 35 responden yang menunjukkan respon positif dan modul praktikum dikategorikan layak dengan nilai rata-rata 83,4 .

Begitu pula penelitian yang diteliti oleh Andik Setiawan (2017) dengan judul "Pengembangan Buku Praktikum Fisika Berbasis Open Ended Problem untuk Siswa SMA N 1 Banguntapan Kelas XI pada Pokok Bahan Elastisitas dan Gerak Harmonik", menyatakan bahwa buku praktikum mudah digunakan, akan tetapi ada beberapa hal yang menghambat, salah satunya adalah menentukan konsep praktikum yang akan dilakukan dikarenakan peserta didik belum terbiasa sehingga perlu untuk dibimbing.

Berdasarkan hal tersebut, peneliti melakukan penelitian untuk mengembangkan modul praktikum fisika berbasis Open Ended Problem yaitu pada pokok bahasan getaran harmonis, guna untuk memberikan pengalaman langsung kepada peserta didik supaya dapat memecahkan permasalahan lebih dari satu penyelesaian jawaban yang benar. Selanjutnya, peneliti mengumpulkan informasi melalui observasi dan wawancara berdasarkan potensi dan masalah yang diperoleh. Sehingga perlu adanya pengembangan modul praktikum fisika berbasis open ended problem pada pokok bahasan getaran harmonis.

Dalam pembuatan desain modul praktikum terdiri dari halaman sampul, halaman francis, kata pengantar, daftar isi, peta konsep, pendahuluan yang berisi kegiatan belajar pada bahasan getaran pada pegas dan ayunan bandul sederhana, penutup, penutup, glosarium, daftar pustaka, dan profil penulis. Setelah tahap pembuatan desain selesai, selanjutnya modul praktikum fisika berbasis open ended problem divalidasi oleh dua orang dosen fisika.

Berdasarkan saran dan masukan dari kedua validator kemudian dilakukan tahap revisi desain untuk menyempurnakan modul praktikum fisika yang dikembangkan dan membuat produk sesuai dengan jumlah responden. Adapun saran dan masukan dari kedua validator sebagai berikut:

a. Modul praktikum sudah bagus, tidak perlu direvisi. Diharapkan modul praktikum nantinya akan dikembangkan lagi pada saat S2, sehingga modul tidak berupa buku cetak, tetapi modul elektronik yang bisa diakses melalui Handphone.

b. Foto Albert Einstein yang sedang menjulurkan lidah pada bagian FYM (for your motivation) diganti dengan foto Albert Einstein lainnya (yang lebih sopan).

Selanjutnya peneliti melakukan uji cobba produk kepada peserta didik MIPA MAN 5 Cirebon yang berjumlah 9 orang peserta didik. Pada tahap uji coba, produk ini bertujuan untuk mengetahui respon peserta didik terdhadap modul praktikum fisika berbasis open ended problem melalui uiji keterbacaan dan kelayakan pengembangan produk.

Berdasarkan hasil validasi dari kedua validator, dapat dikatakan bahwa modul praktikum fisika berbasis open ended problem yang dikembangkan layak untuk dikatakan sebagai bahan 
ajar di sekolah. Hal ini dapat dilihat dari rata-rata skor validasi yang ditunjukkan pada Tabel 3 di bawah ini yang masing-masing komponen memperoleh penilaian hampir sama yaitu Sangat Baik (SB).

Tabel 3. Skor Validasi Modul Praktikum Fisika

\begin{tabular}{lll} 
Komponen & Skor Rata-rata & Kategori \\
\hline Kebenaran konsep & 5 & SB \\
Tingkat keterlaksanaan praktikum & 5 & SB \\
Tampilan fisik praktikum & 5 & SB \\
Kebahasaan & 5 & SB \\
ERerata & 5 & SB \\
\hline
\end{tabular}

Berdasarkan hasil analisis dari komponen respon peserta didik pada setiap komponen diperoleh skor rerata yaitu, pada komponen kebenaran konsep 4,04 (80,86\%), komponen tingkat keterlaksanaan praktikum dengan indikator kemudahan pelaksanaan adalah 4,00 (80,00\%), komponen tampilan fisik dengan indikator desain dan gambar adalah 3,78 $(75,60 \%)$, dan komponen kebahasaan dengan indikator penggunaan bahasa dan kejelasan kalimat adalah 4,26 (85,18\%). Sehingga rata-rata skor dari hasil kuisioner respon peserta didik 4,02 (80,40\%). Rata-rata skor yag diperoleh termasuk dalam interval kategori Baik (B), maka modul praktikum fisika berbasis Open Ended Problem pada pokok bahasan getaran harmonis layak untuk digunakan sebagai salah satu bahan ajar di laboratorium sekolah. Dari keempat komponen penjelasan di atas, dapat dilihat pada Tabel 4.

Tabel 4. Hasil Angket Respon Peserta Didik

\begin{tabular}{|c|c|c|}
\hline Komponen & Skor Rata-Rata & Kriteria \\
\hline Kebenaran konsep & 4,04 & B \\
\hline Tingkat keterlaksanaan praktikum & 4,00 & B \\
\hline Tampilan fisik & 3,78 & B \\
\hline Kebahasaan & 4,26 & SB \\
\hline$\sum$ Rerata & 4,02 & B \\
\hline
\end{tabular}

Sehingga, berdasarkan penilaian dari kedua validator dan 9 peserta didik, bahwa modul praktikum fisika berbasis open ended problem pada pokok bahasan getaran harmonis layak untuk digunakan dan diperbanyak.

\section{KESIMPULAN}

Dari penelitian yang dilakukan telah dihasilkan Modul Praktikum Fisika berbasis Open Ended Problem pada pokok bahasan Getaran Harmonis dengan menggunakan delapan tahapan Sugiyono yaitu potensi dan masalah, pengumpulan data dan informasi, desain produk modul praktikum fisika, validasi modul praktikum fisika, dan produk akhir. Kelayakan Modul praktikum fisika berbasis Open Ended Problem pada pokok bahasan getaran harmonis layak digunakan sebagai salah satu bahan ajar dan termasuk dalam kategori Baik. Respon peserta didik terhadap modul praktikum fisika berbasis open ended problem pada pokok bahasan getaran harmonis masuk dalam kategori Setuju (S).

\section{SARAN}

Berdasarkan hasil dan pengalaman dalam penelitian yang sudah dilakukan, maka dapat disampaikan saran demi kelancaran dan perbaikan kegiatan pengembangan bahan ajar selanjutnya, adapun saran yang dapat peneliti sampaikan adalah penelitian dan pengembangan yang dilakukan ini, peneliti mendapatkan hasil penelitian validasi sangat baik dan respon peserta didik baik di MAN 5 Cirebon. Oleh karena itu, peneliti mengharapkan penelitian ini dapat diujicobakan pada MA/SMA lainnya. Bagi peneliti yang mengembangkan penelitian ini dalam tahap lanjutan, sebaiknya untuk meninjau terlebih 
dahulu latar belakang peserta didik, karena pendekatan open ended problem kurang cocok untuk diterapkan pada peserta didik yang memiliki daya pikir lemah. Disarankan bagi peneliti yang ingin mengembangkan modul praktikum fisika, sebaiknya meninjau pokok bahasan terlebih dahulu, karena peserta didik yang belum terbiasa dengan pendekatan open ended problem sehingga peserta didik perlu dibimbing terlebih dahulu.

\section{UCAPAN TERIMA KASIH}

Penelitian ini dilaksanakan atas izin dari Universitas Sarjanawiyata Tamansiswa dan MAN 5 Cirebon, oleh karena itu penulis mengucapkan terima kasih banyak atas dukungannya selama ini.

\section{DAFTAR PUSTAKA}

Ahmadi, Rulam. 2014. Pengantar Pendidikan (Asas dan Filsafat Pendidikan). Yogyakarta : Ar-Ruz Media

Borg, Walter R. \& Gall, Meredith D. 1983. Educational Research: An Introduction. New York: Longman.

Fitriyani, Siti N. 2017. Pengembangan Modul Fisika Berbasis SETS untuk Memberdayakan Kemampuan Berpikir Kritis Siswa. NTB: Jurnal Kappa, Pendidikan Fisika FKIP Universitas Hamzanwadi Vol. 1. No. 2. Desember 2017

Lahra, Ayel Sarwono dkk. 2017. Pengembangan Modul Praktikum Berbasis Pendekatan Open Ended Untuk Meningkatkan Kreativitas Siswa. Jurnal Pendidikan Sains Indonesia, Vol. 05, No.01, hlm 36-43, 2017.

Putri, Anisa A. Dkk. 2020. Pengaruh Penerapan Model Pembelajaran Inkuiri Terbimbing dengan Praktikum Konversi Energi Panas ke Listrik untuk Meningkatkan Kemampuan Berpikir Kritis. NTB: Jurnal Kappa, Pendidikan Fisika FKIP Universitas Hamzanwadi Vol. 4. No. 2. Desember 2020

Setiawan, Andik. 2017. Pengembangan Buku Praktikum Fisika Berbasis Open Ended Problem Untuk Siswa SMA $N 1$ Banguntapan Kelas XI Pada Pokok Bahasan Elastisitas dan Gerak Harmonik. Jurnal Pendidikan Fisika. Diakses tanggal 16 Januari 2020.

Sugiyono. 2013. Metode Penelitian Pendidikan (Pendidikan Kuantitatif, Kualitatif dan $R$ \& $D)$. Bandung: Alfabeta.

Suharso. 2011. Kamus Besar Bahasa Indonesia. Semarang: Widya Karya

Widoyoko, Eko Putro. 2017. Teknik Penyusunan Instrumen Penelitian. Yogyakarta: Pustaka Pelajar.

Widoyoko, Eko Putro. 2016. Teknik Penyusunan Instrumen Penelitian. Yogyakarta: Pustaka Pelajar.

Wijaya, A. (2012). Pendidikan Matematika Realistik. Yogyakarta: Graha Ilmu 